\title{
POWER AND THE ASCENDANCE OF NEW ECONOMIC POLICY IDEAS Lessons from the 1980s Crisis in Israel
}

\author{
By RONEN MANDELKERN and MICHAEL SHALEV*
}

In short, if we want to accord ideas an explanatory role in analyses of public policy making, we need to know much more about the conditions that lend force to one set of ideas rather than another in a particular historical setting.

-Hall 1989, 362

TNSPIRED by Peter Hall's suggestion, but modifying it in keeping with current interest in the role of ideational entrepreneurs, this article examines the conditions that lend force to the proposals of one group of idea carriers rather than to those of another. The contemporary economic crisis, which raises the possibility of new policy paradigms challenging both neoliberal and Keynesian orthodoxy, adds renewed urgency to the perennial question of the role of ideas in the politics of radical economic policy change. In the scholarly arena recent actor-centered institutionalism has grappled anew with the problem of specifying the mechanisms that make innovative policy ideas matter. ${ }^{1}$ Extending Heclo's classic terminology, Blyth argues that the mechanisms by which an economic crisis is resolved through institutional change are not limited to either puzzling, an apolitical process of discovering workable policies, or powering, political struggles between self-interested actors. ${ }^{2}$

\footnotetext{
* The authors gratefully acknowledge suggestions from the anonymous reviewers and comments from Mark Blyth, Michal Frenkel, Lev Grinberg, Desmond King, Michal Koreh, Jon Kvist, Robert Lieberman, Johannes Lindvall, Omri Metzer, Tami Oren, Craig Parsons, Zeev Rosenhek, Vivien Schmidt, and Leonard Seabrooke. This research was funded by fellowships to Mandelkern from the Department of Political Science and the Cherrick Center at the Hebrew University and by a grant to Shalev from the Israel Science Foundation.

${ }^{1}$ Blyth 2003; Schmidt 2008; Steinmo 2008.

${ }^{2}$ Blyth 2007.
} 
Rather, Blyth suggests, momentous shifts in policy are driven mainly by a political process of persuasion, which rests on the ability of idea carriers to convince other agents that a novel, even alien policy paradigm is in their interest. However, like other attempts to compare the role of ideas with alternative explanations for policy innovation, Blyth's tripartite framework overstates the distinction between power and ideational influences. Clearly, not all ideational entrepreneurs are capable of causing actors to alter their understanding of what went wrong in the economy and how to fix it. Persuasion is in fact a classically political process in which the power resources of idea carriers can be expected to play a decisive role.

Our research concerns the role of ideational entrepreneurs belonging to the "knowledge elite," 3 who petition decision makers on the basis of their expertise rather than on grounds of either formal authority or self-interest. In keeping with recent work by Lindvall suggesting that experts influence the choice of policy instruments rather than policy objectives, ${ }^{4}$ our empirical study refers to initiatives that sought to overhaul the means rather than the ends of economic policy. Our central theoretical claim is that in order to shape the selection of policy instruments, experts must first possess and then successfully employ specific types of power resources.

To illustrate this claim, we exploit a fortuitous natural experiment that occurred in Israel during the first half of the 1980s. Two similar proposals for far-reaching economic reform that shared the same objectives and were advocated under similar institutional and economic conditions experienced divergent fates. Both sought to resolve a rapidly escalating economic crisis characterized by spiraling inflation and a persistent balance-of-payments deficit. Whereas the dollarization plan of 1983 was rejected outright, the 1985 stabilization plan was both accepted and implemented, contributing decisively to the subsequent radical liberalization of Israel's political economy. ${ }^{5}$ Comparing these two attempts at policy innovation in order to study ideational influence on institutional change offers four advantages. First, both initiatives were radically innovative. Based on essentially the same nonconformist ideas, they explicitly sought to break with prior approaches to resolving

${ }^{3}$ King 1999.

${ }^{4}$ Lindvall 2009.

5 "Dollarization" was the media's unofficial name for the 1983 plan, when it was prematurely disclosed and aborted in October of that year. The formal title of the July 1985 stabilization program was the Emergency Economic Stabilization Plan. It was considered such a success that it served as a model for other countries and inspired comparisons with other stabilization reforms. See, for example, Barkey 1994; Bruno 1993; Bruno et al. 1988. 
a major economic crisis. Second, both were launched under conditions usually viewed as conducive to far-reaching institutional change: instability, uncertainty, and erosion of prior conceptual frameworks. Third, since institutional structure and economic conditions were both very similar when the two proposals were floated, many possible explanations can be ruled out. Fourth, these were not competing plans. Because two fairly distinct groups of idea carriers tabled similar proposals over a short period of time, this is a particularly favorable setting for discovering what determines the ability of experts to convince decision makers to turn their ideas into policy.

According to the conventional wisdom in Israel, the contrasting fate of the two programs is explained by what Blyth calls puzzling. The successful plan is understood to have incorporated substantial technical advances that had not been present in its unsuccessful predecessor. However, the evidence presented below reveals that in terms of their content, the two economic programs were actually very much alike. Both relied on the same unorthodox principle that in order to achieve stability, fiscal and monetary restraint would have to be accompanied by monetary anchoring. Explanations based on the traditional understanding of powering are also of little help, since neither the interests of classes, sectors, and state institutions nor their power to realize these interests changed very much between 1983 and 1985. The political capacities of the government are a notable exception, since they increased significantly between these two moments in time. We will argue, however, that this development should be understood as a change in short-term political contingencies that opened a wider window of opportunity for adoption of a radical economic reform but did not determine which — if any — of the available policy proposals would win the government's approval. The contrasting fate of the two emergency programs was rooted in the differential persuasiveness of the ideational entrepreneurs who promoted them-and this, we contend, was primarily a function of the power resources at their command.

\section{The Problem of Power in Ideational Theories}

In the subfield that Campbell and Pedersen ${ }^{6}$ named discursive institutionalism, current thinking has converged on the suggestion that thoroughgoing shifts in policy are mainly the result of persuasion. In Schmidt's words, this means "the ability of agents with good ideas to

\footnotetext{
${ }^{6}$ Campbell and Pedersen 2001.
} 
use discourse effectively"; in Blyth's pithier formulation, it is "exhortation and prodding." "Focusing on persuasion represents an important departure from explaining the potency of policy ideas solely on the basis of their intrinsic properties, such as the degree to which they are familiar, parsimonious, or feasible. Instead, it brings to the fore an emphasis - with which we are in complete agreement - on the agency of idea carriers as active political animals who "establish institutional and political support for ideas to translate into policy action."

Schmidt has recently argued in this vein that proponents of new ideas, if they are to succeed, must exercise discursive agency in enlisting like-minded allies and framing their ideas for public consumption. ${ }^{9}$ But like most other explanations of the political power of economic ideas, this perspective inadequately captures the causal role of power itself. Schmidt's writings recognize equally that power may emanate from ideas and that powerful interests ("veto players") are capable of defeating promising new ideas. ${ }^{10}$ What is missing is attention to the characteristics of specific ideational entrepreneurs, ${ }^{11}$ in particular, the power resources that grant them a priori persuasiveness even before they take up the challenge of "using discourse effectively."

This lacuna is probably the result of the developmental sequence of scholarship on the politics of economic policy change and on institutional change more broadly. Ideational accounts initially challenged established models that showcased either powerful interests or embedded institutional structures. Ideas were seen as having the ability to redefine or even overrule interests, thereby offsetting the effects of economic and political power. Subsequent, more nuanced scholarship sought to demonstrate that explanations based on ideas and power may in fact be complementary. ${ }^{12}$ An example is Hansen and King's comparison of the impact of eugenics advocacy in Britain and the United States: they showed that the fate of similarly influential ideas was sealed by the balance between politically powerful supporters and opponents. ${ }^{13}$ Another noteworthy illustration is Blyth's interpretation of the 1980s campaign by Swedish employers against trade union challenges to established managerial prerogatives. ${ }^{14}$ According to Blyth, the exercise of

\footnotetext{
${ }^{7}$ Blyth 2007, 770; Schmidt 2009, 11.

${ }^{8}$ Widmaier et al. 2007, 754. See also Payne 2001; Risse 2000.

${ }^{9}$ Schmidt 2008; Schmidt 2009.

${ }^{10}$ For example, Radaelli and Schmidt 2004.

${ }^{11}$ Cf. Hansen and King 2001, 257.

${ }^{12}$ See, for example, Berman 2001.

${ }^{13}$ Hansen and King 2001.

${ }^{14}$ Blyth 2001; Blyth 2002.
} 
raw power in the form of lockouts proved insufficient to deflect labor's new demands, and the battle was ultimately won by promoting the idea that only capitalists are capable of producing reliable economic performance. In other words, as thinkers like Gramsci and Foucault have long insisted, ideas are a potentially indispensable source of power. At the same time, the success of the ideological offensive waged by Swedish employers rested on the extensive power resources they were able to bring to bear. That is, as the present article also claims, it takes power to change ideas.

In Blyth's Swedish case study, the power to change ideas originated in the financial and organizational resources of the employers' association and with the ability of business to influence public opinion through the mass media outlets and think tanks under its control. Clearly, however, factors that are relevant to self-interested actors engaged in class conflict are not necessarily salient for understanding the conditions under which seemingly disinterested experts and officials promote radical policy innovations. ${ }^{15}$ In synthesizing the insights offered by contemporary institutionalism for studying how such institutional entrepreneurs sway decision makers, John Campbell states (Proposition 7): "One program for institutional innovation is more likely to precipitate institutional change than another if the entrepreneurs who advocate it command more resources with which to sway key decision makers than their competitors." ${ }^{16}$ The critical questions are what kind of power resources are relevant and under what conditions they are most likely to matter.

Campbell's volume offers much advice on the latter question but little on the former. ${ }^{17}$ However, his earlier study of the rise of supplyside thinking in economic policy concluded that these ideas "captured the imagination of policy makers in part, but not entirely, because they were connected to the organizational resources of powerful political and economic interests." ${ }^{18}$ Like Blyth's study of the Swedish employers, this formulation builds a much-needed bridge between newer explanations based on persuasion and older ones rooted in powering. It suggests that ideational entrepreneurs are more likely to persuade policymakers to take a new idea on board if they enjoy the implicit or explicit support of powerful sponsors. ${ }^{19}$ This of course is the mirror image of Schmidt's suggestion, as well as Hansen and King's demonstration,

\footnotetext{
${ }^{15} \mathrm{It}$ is of course true that experts have an interest in enhancing their own reputation and influence, and legitimizing their authority by exaggerating their own disinterestedness (Cox 2001, 35; Keren 1995).

${ }^{16}$ Campbell 2004, 179.

${ }^{17}$ See, however, Campbell 2004, 76, 154.

${ }^{18}$ Campbell 1998, 379.

${ }^{19}$ See also Goldstein 1993, 15.
} 
that powerful veto players have the ability to torpedo new ideas. However, we contend, in addition, that idea carriers have power resources of their own that may be decisive in determining whether their ideas are translated into policies.

In search of analytical tools capable of shedding light on the relative power of the groups of experts compared in this study, we draw inspiration from two underutilized sources. One of these is the vocabulary provided by Pierre Bourdieu for evaluating the multiple types of power resources ("capitals") contributed by the individual members of the teams that developed the dollarization and stabilization plans. The other is literature that unpacks the group-level sources of power potentially mobilized by what Sabatier and Jenkins-Smith describe as "advocacy coalitions." ${ }^{20}$ We will say more about these tools and their usefulness later. In what follows we first describe the context in which the two economic programs were developed and present evidence for our contention that the content of the proposed policies was very similar. This will clear the way for the task of demonstrating the limitations of prevailing theories in explaining why one plan was adopted whereas the other was not, and then presenting our own solution to the puzzle.

\section{Two Programs, One Economic IdeA ${ }^{21}$}

The era of economic crisis that sparked the two reform proposals scrutinized in this study was ushered in by the dramatic events of 1973. Following the October ("Yom Kippur") war between Israel, Egypt, and Syria and the ensuing international oil crisis, Israel entered a period of stagflation that lasted for more than a decade. Along with greatly diminished growth rates the economy experienced severe inflation, rising from an annual rate of about 40 percent in the mid-1970s to more than 400 percent a decade later, accompanied by a large balance-of-payments deficit (Figure 1). However, largely because of the growth of the military and civilian public sectors, the labor market until 1980 was characterized by what economists considered to be virtual full employment. ${ }^{22}$

\footnotetext{
${ }^{20}$ Sabatier and Jenkins-Smith 1993.

${ }^{21}$ Research for this article was based mainly on the literature on Israel's economic problems and policies during the years 1980-85 and on interviews with key figures involved in macroeconomic policy-making in that period. Contemporary policy ideas were primarily tracked via the Israeli Economic Quarterly (Riv'on Le'Kalkala), a central stage for debates on economic policy between economists from both academia and the bureaucracy. Interviews are identified in citations by the letters INT. A full list can be found in the appendix.

${ }^{22}$ See Ben-Porath 1986; Plessner 1994. In the 1970s the unemployment rate fluctuated between 3 and 4 percent, rising in the first half of the 1980s to 5-6 percent. Source: Bank of Israel Annual Report for 1999, Appendix Table D-4.
} 


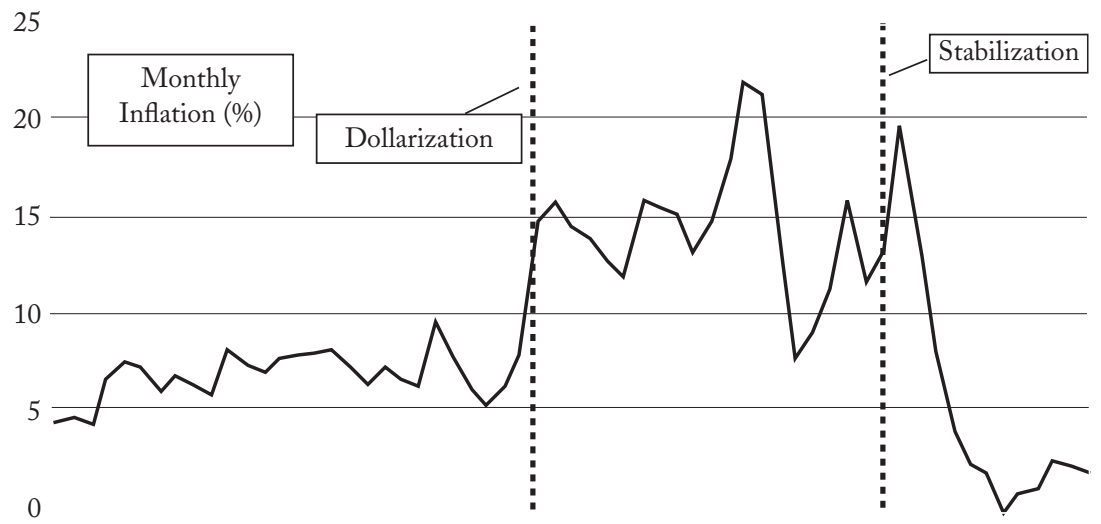

Jun- Sep- Dec- Mar- Jun- Sep- Dec- Mar- Jun- Sep- Dec- Mar- Jun- Sep- Dec- Mar- Jun- Sep- Dec- Mar- Jun$\begin{array}{lllllllllllllllllllll}81 & 81 & 81 & 82 & 82 & 82 & 82 & 83 & 83 & 83 & 83 & 84 & 84 & 84 & 84 & 85 & 85 & 85 & 85 & 86 & 86\end{array}$

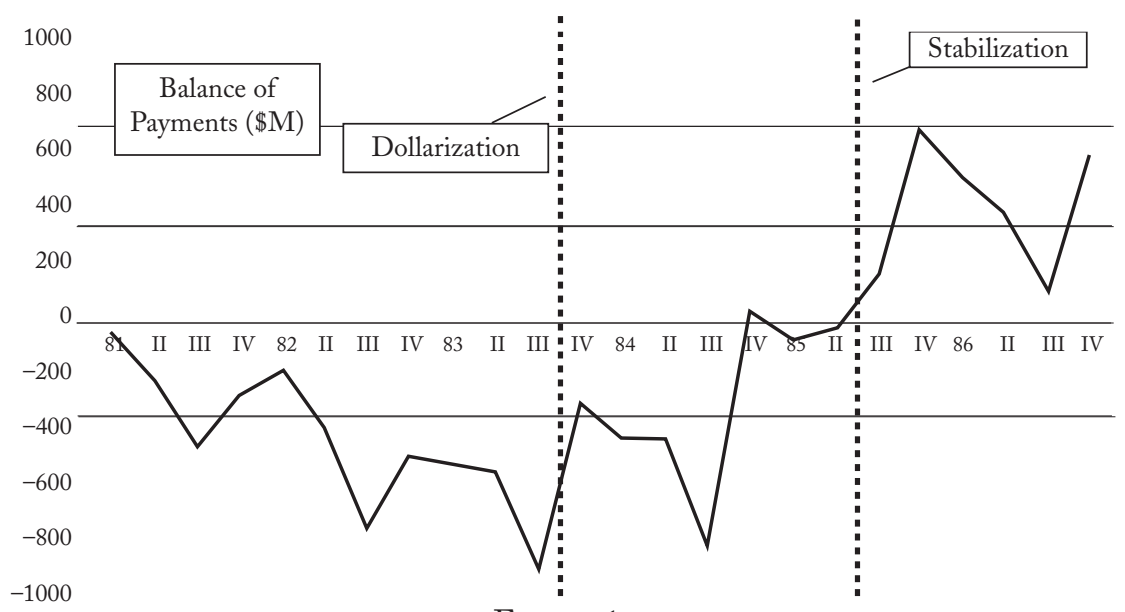

Figure 1

ISRAEL: KeY MACROECONOMIC INDICATORS

${ }^{a}$ Inflation: percent change in CPI since previous month, 3 -point weighted moving average $(\mathrm{t}-2=.2$, $\mathrm{t}-1=.3, \mathrm{t}=.5$ ). Source: Central Bureau of Statistics (www.cbs.gov.il), Series 120010, accessed March 22, 2010. Balance of payments: Balance of payments on current account, millions of dollars at current prices, 3-point weighted moving average ( $\mathrm{t}-2=.2, \mathrm{t}-1=.3, \mathrm{t}=.5)$. Source: Bank of Israel (www.bankisrael .gov.il), Series BOP.NC1000N3.Q, accessed March 22, 2010.

Moreover, for many sectors inflation was much less threatening than its quantitative magnitude would seem to imply. The wages of organized workers included an automatic cost-of-living allowance, and income tax rates and most saving instruments were fully indexed. ${ }^{23}$

Because consumers in Israel were almost completely protected

${ }^{23}$ Kleiman 1984; Plessner 1994; Plessner and Young 2005. 
from inflation, many contemporary economic analysts argued that the balance-of-payments deficit was Israel's most pressing economic problem. ${ }^{24}$ The main macroeconomic tool used to combat the external deficit was devaluation, but in practice this strategy was largely selfdefeating. The hope was that devaluations would increase the profitability of exports, while also cooling domestic demand by eroding wages. ${ }^{25}$ The consequences were quite the opposite, as real wages were pushed upward by both indexation and collective bargaining, especially in the private sector. ${ }^{26}$

Throughout the decade that followed the 1973 war, macroeconomic policy in Israel swung like a pendulum between the competing priorities of reducing inflation and improving the balance of payments. A key feature of the dollarization and stabilization plans was the attempt to address both of these goals simultaneously. ${ }^{27}$ The shared assumption of both programs - that spiraling inflation in Israel was only partially the result of the government's budget deficit—set them apart from the accepted economic wisdom of the time. Fiscal restraint alone would be incapable of generating price stability so long as import price shocks and indexation mechanisms continued to transmit devaluations into local prices. ${ }^{28}$ Moreover, because some of these mechanisms had the effect of eroding the government's real income, some fiscal problems could be addressed only by halting inflation, rather than the other way around. If the budget deficit was partly to blame for spiraling inflation, this was mainly due to its indirect influence on the balance of payments. $^{29}$

The conclusion reached by the designers of both the dollarization and the stabilization programs was that in order to combat inflation the government should adopt a "nominal anchor" that linked local prices and other values to foreign currency. In combination with budgetary restraint, this would signal the public that the inflationary spiral had come to an end, thereby ending the inertia that newly popular rational expectations theories believed to be the result of inflationary expectations. ${ }^{30}$ But within this shared "heterodox" (nonorthodox) approach to stabilization there were two important differences between the programs. First, while the stabilization plan was based on freezing the

\footnotetext{
${ }^{24}$ See, for example, Bronfeld 1975; Gafni 1977; Yoran 1978.

${ }_{25}$ Plessner and Young 2005; Rubin 1984; Rubin-INT 1988, 2007.

${ }^{26}$ Grinberg 1991; Plessner 1994.

${ }^{27}$ Bank of Israel Annual Report for 1986, 3; Maman and Rosenhek 2007, 258.

${ }_{28}^{28}$ Bruno et al. 1988; Liviatan and Piterman 1984; Plessner 1984a; Plessner 1984b; Rubin 1984.

${ }^{29}$ Bruno 1985, 211; Plessner 1983, 744, 754.

${ }^{30}$ Barkey 1994; Bruno 1993.
} 
exchange rate, the earlier plan acquired the name "dollarization" because its authors seriously considered adopting the U.S. dollar as Israel's exclusive legal tender. ${ }^{31}$ The second difference concerns the extent of planned budget cuts. The perception of inflation as a cause rather than a consequence of the fiscal deficit was especially strong among some of the designers of the dollarization plan, who proposed relatively modest budget cuts of about half a billion U.S. dollars, compared with the $\$ 1.5$ billion envisaged by the stabilization plan. Nevertheless, a significant component of this change was simply the increase in the budget deficit during the twenty months that passed between rejection of the dollarization plan and adoption of the stabilization plan. ${ }^{32}$

Both programs shared additional features designed to complement their basic framework. One was an amendment to the Bank of Israel Law to prohibit the central bank from providing loans to the government for financing budgetary deficits, a practice known in Israel as "printing money." ${ }^{3}$ Additionally, in both cases the U.S. was committed to providing the Israeli government with substantial financial aid, conditional on its implementation of an economic reform program. ${ }^{34}$

Table 1 provides a more detailed comparison of the two economic plans. It is clear that with regard to their central goal, which was rapid stabilization, both were based on the same economic logic and the use of very similar policy tools. However, as compared with the dollarization plan, the stabilization plan included some additional components, including layoffs in the public sector and other long-term measures aimed at restructuring and liberalizing the Israeli economy. We comment later in the article on the possible significance of these additions for the acceptance of the stabilization plan.

\section{The Limited Applicability of Prevailing Explanations}

In order to make a convincing case for our preferred interpretation of the contrasting fates of the two economic plans, our first obligation is to rule out the most prominent alternatives. Most, although not all, of these explanations can be conveniently summarized under Blyth's headings of puzzling, powering, and persuasion.

The basic puzzling explanation is straightforward: the stabilization plan was accepted because it was better than the dollarization plan;

${ }^{31}$ Aridor-INT 2007; Dollarization Colloquium 1984; Plessner 1984b.

${ }^{32}$ Meridor-INT 2007.

${ }^{33}$ Maman and Rosenhek 2007.

${ }^{34}$ Aridor-INT 2007; Bruno 1993; Naor-INT 2008; Plessner-INT 2007; Sadan-INT 2007; SharonINT 2007. 
TABLE 1

Comparison of the Dollarization and Stabilization Programs ${ }^{\mathrm{a}}$

\begin{tabular}{|c|c|c|}
\hline & Dollarization Plan & Stabilization Plan \\
\hline \multicolumn{3}{|c|}{ Economic Logic } \\
\hline $\begin{array}{l}\text { Causes of } \\
\text { Inflation }\end{array}$ & $\begin{array}{l}\text { Escalating inflation is mainly a result } \\
\text { of the repeated devaluations carried } \\
\text { out in order to improve the balance of } \\
\text { payments. }\end{array}$ & $\begin{array}{l}\text { In the short run escalating inflation is } \\
\text { mainly a result of repeated devaluations. } \\
\text { The budget deficit also contributes, but } \\
\text { mainly in the longer term. }\end{array}$ \\
\hline $\begin{array}{l}\text { Impact of the } \\
\text { Budget Deficit }\end{array}$ & $\begin{array}{l}\text { The budget deficit causes the bal- } \\
\text { ance-of-payments deficit, indirectly } \\
\text { contributing to inflation. }\end{array}$ & $\begin{array}{l}\text { The budget deficit causes the balance- } \\
\text { of-payments deficit and aggravates the } \\
\text { burden of government's foreign debt. }\end{array}$ \\
\hline
\end{tabular}

\section{Program Components}

Fiscal Policy Fiscal restraint is part of the plan but Fiscal restraint is emphasized, including is downplayed on the assumption that it will be politically difficult to implement. Planned budget cut of U.S. $\$ .5 \mathrm{~B}$ when the deficit was 6.2 percent of GDP. public sector employment cuts. Recommended budget cut was U.S. $\$ 2.25 \mathrm{~B}$; actual cut was $\$ 1.5 \mathrm{~B}$ when the deficit was 14.4 percent of GDP.

Exchange Rate A onetime devaluation to be followed by a defined period in which Israel's curPolicy rency would be fixed to the U.S. dollar.

Denomination of local prices in U.S. Exchange rate freeze. dollars, and possible use of the U.S. dollar as exclusive legal tender.

Monetary Amendment of the Bank of Israel Law to prohibit deficit finance by means of Policy "printing money."

Monetary restraint to be achieved by high interest rates. ${ }^{\text {b }}$

Real Wages 10 percent real wage erosion to be achieved by emergency decrees.

Prices Temporary price freeze.

Indexation Legislation to abolish indexation mechanisms.

Reduced liquidity of linked financial assets, suspension of wage indexation until stabilization achieved.

American Aid If U.S. dollar becomes legal tender, a

$\$ 1.5 \mathrm{~B}$ grant over two years. guarantee of up to $\$ 1.5 \mathrm{~B}$ in case the government runs out of dollars.

Additional Components

Planned long-term structural reforms, especially liberalization of the local capital market

SouRCEs: Dollarization plan: Al Ha'Mishmar 1983; Aridor-INT 2007; Plessner 1984b; Plessner-INT 2007. Stabilization plan: Bruno 1985; Bruno 1986; Bruno and Fischer 1986; State of Israel 1985.

aBudget deficit calculations under "Fiscal Policy" are based on Bank of Israel, Annual Report for 2001, Appendix Table A-3.3. Data are for the end of 1983 (dollarization) and the end of 1984 (stabilization).

${ }^{\mathrm{b}}$ Not included in the original program but incorporated after a later government decision. 
specifically, it was more comprehensive and better suited to economic conditions in Israel. ${ }^{35}$ This explanation falls short, however, because it overstates the differences between the programs. Moreover, it rests on the fallacy of anachronism, because when the stabilization plan was introduced even its designers were uncertain whether it would succeed. ${ }^{36}$ We therefore need to look beyond the content of the policy proposals to understand why dollarization was almost universally rejected by economists in both academia and public administration.

A more sophisticated form of puzzling, called policy learning or social learning, refers to a process of trial and error in which the entry of new ideas is facilitated by updating an existing ideational framework. ${ }^{37}$ The relevant claim in this case would be that the stabilization program marked a significant change with regard to previous plans, as it aimed to address simultaneously the problems of inflation and the balance-ofpayments deficit. This solution, so the argument might go, was based on learning from the failure of previous initiatives that focused on only one or the other of these problems. The problem is that dollarization rested on this assumption as much as stabilization; indeed, the proponents of dollarization were the first to try and translate it into policy.

While interpretations based on puzzling reflect views common among Israeli economists (with the exception of the few who supported dollarization), powering explanations are the traditional stronghold of political economists. Despite differences of opinion regarding the relative weight of the interests of business and the state in explaining the emergence of the stabilization plan, ${ }^{38}$ political economy analyses are united in their view that the stabilization plan was an outgrowth of deep structural and historical forces. But they neglect the question of why the stabilization plan succeeded where the dollarization plan failed. The similarity between the two programs offers no logical room for explaining their contrasting fate by appealing to their congruence or incongruence with the interests of classes, sectors, or the state.

Conspicuously missing from Blyth's explanatory trio is the central claim of the traditional institutionalist approach, that the power of ideas is dependent on institutional structures. Certain characteristics of political and bureaucratic institutions throw up barriers to the entry of new ideas into the decision-making arena or reduce the odds that they will endure. ${ }^{39}$ Given the etatist and decidedly nonporous char-

\footnotetext{
${ }^{35}$ Bruno 1993, 89; Keren 1995.

${ }^{36}$ Bruno 1993, 107.

${ }^{37}$ Hall 1993.

${ }^{38}$ Grinberg 1991; Nitzan and Bichler 2002.

${ }^{39}$ See, for example, Risse-Kappen 1994; Weir 1989.
} 
acter of Israel's highly centralized state at the time, ${ }^{40}$ this literature would lead us to expect that new ideas faced relatively severe barriers to entry. Schmidt has recently argued in a similar vein that simple and compound state structures privilege different forms of discourse, the "coordinative" and the "communicative," respectively. ${ }^{41}$ In the context of the corporatist system of interest intermediation that prevailed in Israel in the early $1980 \mathrm{~s},{ }^{42}$ coordinative interaction between elites was indeed more important for marketing new policy ideas than communicative appeals to the mass public. Yet with regard to the puzzle at the center of this article, since institutional structures did not change in the short period under study, institutional conditions per se cannot explain the acceptance of the stabilization plan after the rejection of dollarization.

Another well-established claim in the literature on ideational influences on institutional change is that ideas acquire special importance during periods of crisis and instability. ${ }^{43}$ The argument is that at such times agents are unusually amenable to innovative ideas that make sense of a crisis by offering a credible causal story and defining an appropriate course of action. ${ }^{44} \mathrm{~A}$ long-standing crisis like the one under consideration here ought to further enhance openness to new ideas, since it takes time to uproot existing conceptions and to introduce, discuss, and adopt new ones.

Throughout the first half of the 1980s economists and policymakers in Israel perceived the country's economic situation as catastrophic, providing fertile soil for the emergence of new policy proposals. ${ }^{45}$ The basic economic problems with which the government had to deal-severe price instability and dependence on external resources - had been evident since the late 1970s. Nevertheless, perhaps the success of the stabilization plan can be attributed to the fact that the crisis was even more severe in 1984-85 than it had been previously, when dollarization was under consideration? As shown previously in Figure 1, monthly inflation rose to a range of roughly 5-10 percent in 1981-83 and ratcheted up again to around 10-20 percent during 1984-85. However, already at the time the dollarization plan was disclosed in October 1983, policymakers were well aware that the index to be released at the end of

${ }^{40}$ Kleiman 1997; Levi-Faur 1999.

${ }^{41}$ Schmidt 2008.

${ }^{42}$ Mundlak 2007; Shalev 1992.

${ }^{43}$ Goldstein and Keohane 1993, 16; Hall 1993, 275-76; Hay 2001, 194-96.

${ }^{44}$ Blyth 2002, chap.2.

${ }^{45}$ See, for example, Fischer and Frenkel 1982; Gronau et al. 1984; Leiderman et al. 1979; Razin et al. 1985 . 
that month would signal a new escalation in prices. ${ }^{46}$ Moreover, during the interim period until the stabilization plan was announced at the beginning of July 1985, not all economic indicators consistently heralded bad news. As Figure 1 reveals, the balance-of-payments deficit showed definite signs of improvement prior to adoption of the stabilization plan. ${ }^{47}$ Even more importantly, for experts and policymakers operating in real time and viewing things from the perspective of late 1983, the problem of hyperinflation appeared no less severe than it did on the eve of stabilization-since 1985 was yet to come. ${ }^{48}$ Hence, while crisis and instability may have constituted an essential background factor by offering an opportunity to advance a new approach to economic policy, they cannot explain why one heterodox plan gained acceptance while its predecessor did not.

Persuasion, in the broad sense of creative political agency exercised by ideational entrepreneurs, is the remaining explanatory focus for understanding major policy changes and the one that we ourselves wish to privilege. The argument we elaborate below-first theoretically and then by reference to our empirical cases-aims to show that the persuasiveness of ideas is dependent on the power resources of idea carriers and on how they mobilize these resources. In addition, the contingent political circumstances under which ideational entrepreneurs operate serve either to expand or to contract the receptiveness of decision makers to their policy proposals.

\section{Power, Politics, and Persuasion}

Our approach to identifying the power of idea carriers assumes that they have the potential to mobilize a number of different types of power resources. Pierre Bourdieu's notion of multiple forms of capital furnishes a parsimonious conceptual framework for addressing this multidimensionality. In addition, in cases like the present one, in which

${ }^{46}$ In October 1983 prices rose by 21 percent, three times the average increase during the preceding nine months. This spike resulted from a massive devaluation carried out only days before the dollarization plan was revealed in the media. The devaluation was expected following the failure two months earlier of a policy of simultaneously limiting monthly devaluations and price increases to 5 percent (Plessner 1994, 256-62).

${ }^{47}$ Because of pronounced seasonality in the balance of payments, the clearest evidence of the improvement is that in each of the three quarters that preceded the stabilization plan, there was a marked improvement in the current account balance in comparison with the parallel quarter a year earlier.

${ }^{48}$ Indicative of perceptions of the depth of the crisis at the time dollarization was under consideration, on October 11, 1983, the London Times reported that the acrimonious debate surrounding the formation of Yitzhak Shamir's government the previous day was "overshadowed by an economic situation described by many experts as the grimmest in Israel's history" (Christopher Walker, "Shamir takes office amid panic," 5). 
new ideas are advocated by coalitions of agents rather than by an isolated policy entrepreneur, the power resources of the coalition need to be analytically divided between the combined resources of individual members and the strength of the coalition itself. On this score, as will shortly be detailed, we borrow insights from research on policy transfer and advocacy coalitions.

The concept of capital stands at the center of Bourdieu's political economy of symbolic power. ${ }^{49}$ While Bourdieu's conceptualization was originally developed for the analysis of broad social categories, there is no reason in principle why it cannot be a powerful tool for microlevel analysis. Some individual idea carriers enjoy what may be termed "conventional" political power resources-electoral, organizational, or formal. Academic experts, who are the main agents on whom we focus here, rely instead on symbolic "academic capital." ${ }^{0}$ For Bourdieu, academic capital consists of what is valued in the field of academia, including achievements such as publications, position in the hierarchies of ranks and institutions, and connections with colleagues within the international academic field. ${ }^{51}$ Also relevant, but not of course unique to academia, is social capital, which according to Bourdieu's definition refers to a person's network of connections and acquaintances. ${ }^{52}$

When active in a policy-making field, academic experts may succeed in converting the assets they have already accumulated-that is, their academic and social capital - into political capital. One obvious basis for such conversion is that a professor's superior academic capital may enhance the legitimacy of the decisions in which she is involved, in the eyes of bureaucrats, politicians, or the public. Since most senior elected and appointed public officials are graduates of their country's academic system, they may be assumed to be familiar with its status hierarchy. However, the literature on the role of experts asserts that academic reputation is a basis for commanding the attention of decision makers above and beyond their contribution to legitimating policies. This is explained by the knowledge held by experts and the social status attached to their role. The prestige that they enjoy strengthens their authoritative claim to knowledge of complex policy issues on which decision makers are dependent, especially in periods of uncertainty. ${ }^{53}$

\footnotetext{
${ }^{49}$ Bourdieu and Wacquant 1999; Swartz 1997.

${ }^{50}$ We adopt a somewhat simplified version of Bourdieu's categorization of the different types of capital that academics may hold.

${ }^{51}$ Bourdieu 1988.

${ }^{52}$ Bourdieu 1986.

${ }^{53}$ See, for example, Haas 1992; Stone 2002.
} 
The precise rate of exchange between academic and political capital is contingent. ${ }^{54}$ As Hall commented when discussing the impact of differences in the reputation of the exponents of Keynesianism, it varies contextually across time and place. ${ }^{55}$ Conversion of academic capital into political capital also depends, at least in part, on the extent to which individual experts seek out decision makers and actively participate in policy formulation. ${ }^{56}$ The exercise of these types of political agency is sufficiently common among economists that some of them have compared their profession to salesmen competing with other dealers to sell their goods to policymakers. ${ }^{57}$

As in other cases of coordination between multiple actors, the collective power of expert teams of idea carriers is not merely the sum of the resources commanded by their individual members. It also depends on their ability to overcome collective action problems and build group cohesion. In order to address this issue we borrow from two theoretical frameworks: advocacy coalitions and policy transfer networks. ${ }^{58}$ These models are valuable because they draw attention to specific characteristics of advocacy groups that can be identified and compared in empirical research like our own. Briefly, these attributes refer to (1) the conditions surrounding a group's activity, namely, its contestation with rival coalitions and the dependence of decision makers on the group's skills and knowledge; and (2) internal cohesion, based on the existence of a shared belief system, the intensity of interaction between group members, the level of coordination and mutual trust, and exchange relations between group members. The latter feature is salient because extensive gaps between the power resources of the individual members of a coalition/network are thought to raise the odds of defection by those who are more powerful.

The influence of these factors at the specific historical moment of concern to us here is teased out in the next two sections. Some details that are not directly relevant to the present purposes will not be described, but they are readily accessible in the secondary literature on Israel's political economy during the period in which the two economic programs were formulated. ${ }^{59}$

\footnotetext{
${ }^{54}$ Fourcade 2009.

${ }^{55}$ Hall 1989, 375.

${ }^{56}$ Kingdon 1995, 55-56.

${ }^{57}$ Barber 1989; Bruno 1990.

${ }^{58}$ Evans and Davies 1999; Sabatier 1998; Sabatier and Jenkins-Smith 1993.

${ }_{59}$ Bruno 1993; Grinberg 1991; Shalev and Grinberg 1989; Liviatan and Barkai 2004; Plessner
} 1994. 


\section{Coalitions' Power Resources Compared}

\section{Dollarization Plan}

The main proponents of the dollarization program were the minister of finance from January 1981, Yoram Aridor, and his chief economic adviser, Yakir Plessner, who also served as deputy governor of the central bank. Both already suffered from tarnished reputations resulting from their sponsorship of economic policies prior to the dollarization episode that most economists considered misguided and irresponsible. ${ }^{60}$ Early in Aridor's tenure, when elections were only months away and the government's popularity was plummeting, he cut import duties on consumer goods and took other measures ostensibly intended to slow down inflation and improve the living standards of the less well-todo. Critics from both the political and academic arenas derided these measures as "election economics." Aridor subsequently adopted a policy of gradually decreasing devaluations, but it failed to retard inflation because the Histadrut (the peak association of labor) did not cooperate with him in restraining wages. In addition, Plessner, the architect of the dollarization plan, enjoyed only limited academic capital. Although he was tenured, he did not hold a professorial rank and was affiliated with the Department of Agricultural Economics at the Rehovot campus of the Hebrew University, which Israeli economists have always held in far lower esteem than the internationally renowned economics departments located in Jerusalem and Tel Aviv. ${ }^{61}$ Further, the director general of the Ministry of Finance at the time was also an economist from Rehovot.

In addition to government officials from the MoF (Ministry of Finance) and BoI (Bank of Israel), who were chosen mainly on the basis of the positions they held, the team responsible for the dollarization plan included several prominent economists recruited for their academic capital. ${ }^{62}$ For the same reason Ronald I. McKinnon, a Stanford economist with whom Plessner was acquainted, was asked to give the program his blessing. ${ }^{63}$ After the team had worked for several months,

${ }^{60}$ Additional details of these policies and analyses of their failures can be found in Aridor-INT 2007; Plessner 1984b; Grinberg 1991; and Ben-Porath 1983.

${ }^{61}$ See Mandelkern 2006; Frenkel-INT 2007; Pines 1985. Note that for simplicity, universities are referred to by the location of the relevant campus rather than their official names.

${ }^{62}$ Notable among these were Eitan Berglas from Tel Aviv and Nissan Liviatan from Jerusalem (Aridor-INT 2007; Plessner-INT 2007) and Pinhas Zusman from Rehovot, who was an exception to the low esteem in which economists from the Rehovot department were held. Berglas and Liviatan would later exert significant influence on the design of the stabilization program.

${ }^{63}$ Since the program was leaked to the media earlier than planned, its designers were unable to use McKinnon's endorsement (Plessner-INT 2008). 
apparently bringing the plan to within months of implementation, ${ }^{64}$ an outline was leaked to the press. Immediately after the revelation that the planners allegedly intended to replace Israel's currency with the dollar, it was publicly repudiated by the prime minister and other members of his cabinet, and Aridor resigned from office.

The unplanned disclosure of the dollarization plan is not surprising, given the weak internal cohesion of the planning group. Expressing the same lack of unity, Moshe Mandelbaum (governor of the BoI) and economists from the bank's research department went out of their way to point out the alleged deficiencies of the plan to the prime minister and other members of the cabinet. ${ }^{65}$ Mandelbaum also tried to discourage the American administration from supporting the plan, which would certainly have failed without the promised U.S. aid. ${ }^{66}$

\section{Stabilization Plan}

The stabilization program was devised by a small group of government officials and academic economists, including the director general of the MoF, the head of the BoI's research department, the prime minister's economic adviser, and two economics professors-Eitan Berglas from Tel Aviv and Michael Bruno from Jerusalem. ${ }^{67}$ The latter is considered the leading architect of the program, although it has been suggested that its theoretical foundations were laid by Nissan Liviatan, who was not directly involved in the program's design. ${ }^{68}$ All three were among the leading academic economists in Israel and also enjoyed very high status within the broader-mostly American-international epistemic community of economists. ${ }^{69}$

Although the stabilization team was formed less than a month before the plan was endorsed by the government, most of its members had already participated in two previous working groups also charged with designing a stabilization program for the Israeli economy. One was set up just before the general elections of 1984 to formulate an economic plan for the Labor Party in the expectation that it would

\footnotetext{
${ }^{64}$ Aridor and Plessner intended to implement the dollarization plan in December 1983, two months after the unplanned disclosure. See Aridor-INT 2007; Meridor-INT 2007; Plessner-INT 2007; Sadan-INT 2007.

${ }^{65}$ Ben Basat-INT 2007; Frenkel-INT 2007; Mandelbaum-INT 1988, 2007.

${ }^{66}$ Mandelbaum mistrusted the heterodox approach, believing that inflation could be controlled only by dealing with the problem of excess demand by means of fiscal and monetary restraint (Mandelbaum-INT 2007).

${ }^{67}$ Because members of the team mistrusted Mandelbaum, they concealed their work and the involvement of the head of the BoI Research Department from the governor.

${ }^{68}$ Brodet 2005; Gross-INT 2006.

${ }^{69}$ Both Bruno and Liviatan were included in the prestigious "Who's Who in Economics" list published in 1983 (Blaug and Sturges 1983).
} 
form the next government. ${ }^{70}$ The second group was established after a new government was formed, as a condition for receiving financial aid from the U.S. administration. It included American as well as Israeli economists, from both the government and academia. ${ }^{71}$ According to Stanley Fischer, a member of the American delegation, "The idea of including non-government economists, almost certainly George Shultz's [Schultz was the U.S. secretary of state and a well-known economist], was that there were people in Israel, professional economists, who knew what needed to be done, but who were not succeeding in influencing their government's policy." 72 In this way prominent Israeli economists who were the architects of the stabilization plan were able to use their professional and personal connections with their counterparts in the U.S. in order to mobilize political pressure on the Israeli government to implement their policy ideas, which were supported by the American economists. ${ }^{73}$

The accumulated experience of the members of the stabilization team in working as a team promoted mutual trust and facilitated cooperation. ${ }^{74}$ When disagreements arose they were settled within the group or through consultation with the minister of finance and the prime minister. ${ }^{75}$ It is true that in many respects the groups involved in the design of the two programs shared similar characteristics. Both brought together economists from the BoI, the MoF, and the universities and included some degree of involvement on the part of American experts. Within both groups, cooperation was threatened by the reluctance of some members to adopt nominal anchoring, an idea that fractured their shared beliefs. ${ }^{76}$ Moreover, both teams had to deal with competing ideational agents who were seeking to shape economic policy through coordinative discourse. ${ }^{77}$ Several economics professors

\footnotetext{
${ }^{70}$ Berglas-INT 1988; Bruno 1993, 93; Neubach-INT 2007; Sharon-INT 2007.

${ }^{71}$ This team was called the Joint U.S.-Israeli Economic Development Group (the JEDG). For further details, see Gross 2004, 179.

${ }^{72}$ Fischer 2001.

${ }^{73}$ In addition to the role played by Ronald McKinnon, noted previously, according to Aridor-INT 2007, the principles of the dollarization plan were also discussed with Milton Friedman and Herbert Stein, as well as with economists in the U.S. administration. However, only members of the stabilization team utilized connections with American colleagues to render their own ideas more politically compelling.

${ }_{74}^{74}$ Sharon-INT 2007; Frenkel-INT 2007.

${ }^{75}$ Berglas and Aharon Fogel, budget chief at the MoF, were both opposed to a complete freeze of the exchange rate, but the two sides reached a compromise on the issue (Fogel-INT 2007; Shalev and Grinberg 1989, 38). For examples of agreements reached with the help of the political leadership, see Bruno 1993, 101; Gross 2004; Neubach-INT 2007.

${ }^{76}$ Although nominal anchors were adopted in some other countries during this period, in the Israeli context this was considered a radically innovative policy. We found no evidence of diffusion of this idea to Israel from abroad.

${ }^{77}$ See also Bruno 1993, 95, 99.
} 
from Tel Aviv, who remained faithful to the orthodox "budgets cause deficits" view, called for large-scale fiscal restraint without applying any nominal anchor. ${ }^{78}$ There were also two former governors of the central bank who opposed radical political-economic change of any kind and were active in engineering the tripartite agreements on wage and price freezes (package deals) signed in the months preceding stabilization.

While both groups of planners had to compete with alternatives promoted by other ideational entrepreneurs, the advocacy coalition that supported stabilization entered this competition with clear advantages. The most prominent of these was the difference between the academic and social capital of the two teams' leaders. Bruno (stabilization) and Plessner (dollarization) were located, respectively, at the center and periphery of the epistemic community of economists in Israel and worldwide, a fact that was consequential for their political capital in decision-making arenas. Moreover, Bruno (and his fellow academic economist Berglas) possessed greater social and political capital than Plessner due to their prior involvement in the Labor Party and previous experience of working in or with the MoF. ${ }^{79}$ Plessner did not have equivalent assets, as his engagement with politics was limited to his service with Aridor.

The power resources of each individual leader also affected his ability to persuade other team members, to engineer compromises, and to promote group cohesion more generally. Thus, Berglas-who consistently opposed the idea of nominal anchoring-was willing to soften his resistance for Bruno, but not for Plessner. ${ }^{80}$ In both cases he was called upon to risk his academic capital and reputation for a policy that included elements he opposed. Bruno's superior influence over Berglas may be explained in part by the fact that the academic capital that both men were called upon to risk was relatively equal. Whatever the reason, the support of a prominent "orthodox" economist like Berglas strengthened the advocates of stabilization by making it easier for them to dismiss opposition from other economists.

By way of summary, Table 2 specifies the power resources held by the core members of each team, and Figure 2 adds a visual representation of the ties between them in order to portray their collective strength. The

\footnotetext{
${ }^{78}$ Razin 1984a; Razin 1984b; Razin et al. 1985.

${ }^{79}$ Bruno was formerly a senior adviser to the MoF and Berglas had been the head of its Budgets Division.

${ }^{80}$ After the dollarization plan was leaked, Berglas publicly expressed his opposition to it; "Thus It Was Born, and Thus It Died" (in Hebrew). 1983. In Yediot Aharonot. October 14. In contrast, as already indicated (fn. 76), in the formulation of the stabilization plan his disagreement on nominal anchoring with Bruno was settled within the team.
} 
TABLE 2

Power Resources of the Dollarization and Stabilization Teams ${ }^{\mathrm{a}}$

\begin{tabular}{|c|c|c|c|c|}
\hline Person & Institutional Affiliation & $\begin{array}{c}\text { Academic } \\
\text { Capital } \\
A C\end{array}$ & $\begin{array}{l}\text { Social } \\
\text { Capital } \\
S C\end{array}$ & $\begin{array}{l}\text { Political } \\
\text { Capital } \\
f(A C, S C)\end{array}$ \\
\hline \multicolumn{5}{|c|}{ Dollarization (1983) } \\
\hline Plessner & $\begin{array}{l}\text { MoF and BoI; Rehovot Uni- } \\
\text { versity }\end{array}$ & low & low & low \\
\hline Berglas & Tel Aviv University & high & high & high \\
\hline Helpman & Tel Aviv University & high & low & medium \\
\hline Liviatan & Jerusalem University & high & low & medium \\
\hline Sadan & MoF; Rehovot University & low & high & medium \\
\hline Zusman & Rehovot University & high & high & high \\
\hline \multicolumn{5}{|c|}{ Stabilization (1985) } \\
\hline Bruno & Jerusalem University & high & high & high \\
\hline Berglas & Tel Aviv University & high & high & high \\
\hline Frenkel & BoI & - & medium & medium \\
\hline Liviatan & Jerusalem University & high & low & medium \\
\hline Neubach & PM Office & - & medium & medium \\
\hline Sharon & $\mathrm{MoF}$ & - & high & high \\
\hline
\end{tabular}

aTable 2 and Figure 2 focus on the core members of the planning teams, omitting additional individuals who played more peripheral roles. Note that whereas the stabilization team operated as a formally appointed body, the dollarization team was a looser collection of planners and consultants. To simplify references to academic institutions, they are denoted by their location. "Rehovot University" refers to the Department of Agricultural Economics at the Hebrew University's campus in Rehovot.

${ }^{\mathrm{b}}$ Assessment of political capital is based on both the social and academic capital that actors possess.

table illustrates that the critical difference between the two groups in terms of members' individual political capital was the stark contrast in the standing of their leaders. The charts complete the picture by clearly revealing, in addition, the superior strength of the stabilization team from a network perspective. The most tightly linked members of the dollarization team - the leader and two of his academic colleagueswere isolated from other team members, two of whom dissented from the unorthodox ideational foundations of the policies under development. By contrast, the members of the stabilization team were linked by both personal relationships and prior experience of working together, which enabled them to overcome internal conflicts and operate as a robust coalition.

One final element of the superiority of the stabilization team remains to be noted. The power resources at the disposal of ideational 

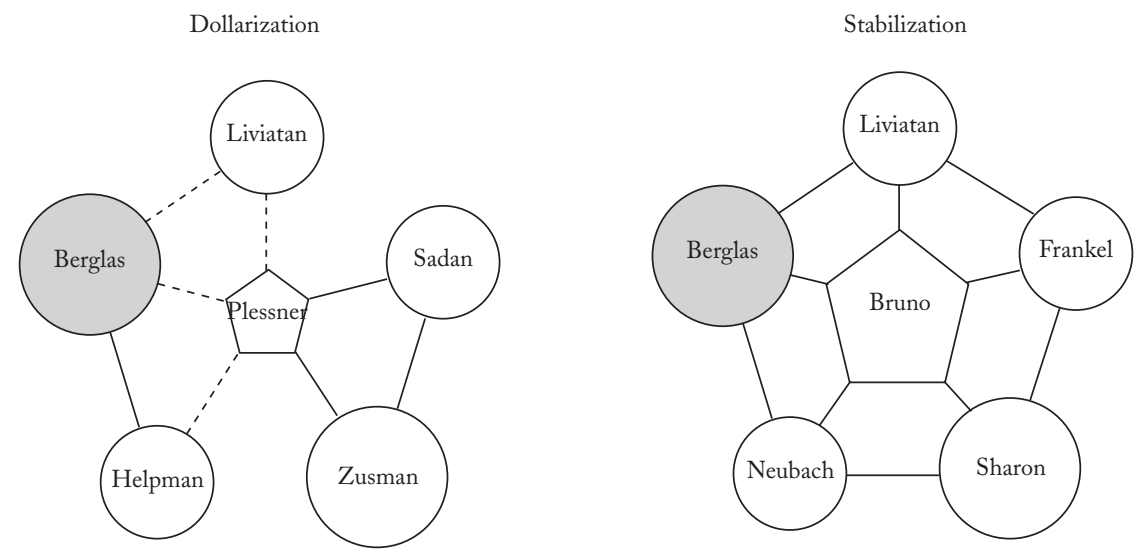

Figure 2

Comparison of the Dollarization and Stabilization Teams ${ }^{a}$

${ }^{a}$ Pentagons represent team leaders, size of shapes indicates extent of political capital (see Table 2), broken lines indicate weak connections, and gray circles represent opponents of "nominal anchoring."

entrepreneurs are not necessarily limited to their preexisting assets; they may also be generated by dynamic political processes. In our study this was evident in the progressive undermining of the dollarization team, compared with the trend toward consolidation of the stabilization team. The stabilization plan benefited from positive feedback as the quiet gestation period under the auspices of the Labor Party gave way to a more official status, which was then parlayed into further state sponsorship through team members' relationships with American economists. The dollarization team experienced negative feedback even before its formation, initially because of the weak reputations of both Aridor and Plessner and later as a result of the plan's disclosure and the bad publicity it generated, causing its academic team members to abandon ship.

\section{Challenges to the Power Resources Approach}

This is an appropriate moment to pause and consider two potential vulnerabilities in our argument, both of which are related to the public relations damage that was wrought by the revelation of Israel's impending "dollarization." The first challenge concerns the importance of effective framing for the success of ideational initiatives, compared with our preferred emphasis on power. The second is the possibility that the decisive advantage of the stabilization team was the result of learning 
from the framing error committed by their predecessors. The first issue questions our theoretical emphasis, while the second points to a possible methodological weakness inherent in the design of our comparison because the two programs were temporally ordered.

Constructivist explanations of the power of policy ideas have emphasized the role played by discursive framing, described by Torfing and Cox as "path-shaping," 81 in defining undesired courses of action as illegitimate or impractical and desired ones as inevitable. In this literature successful framing is often believed to rest on presenting new proposals by means of familiar and consensual ideas. An example is Schmidt's recent suggestion that French president Sarkozy succeeded in the field of pension reform, where others had failed before him, by "refram[ing] the issue in a communicative discourse that resonated with the concept of equality central to the French republican tradition." ${ }^{2}$ In the Israeli context under scrutiny here, the chief architect of the stabilization plan seems to have been more aware than his predecessors of the importance of effective marketing. ${ }^{83}$ "Dollarization" rode roughshod over Israel's highly developed Zionist sensibilities-not only because currency is always an icon of sovereignty but specifically because the shekel had been introduced only three years earlier as a symbolic assertion of the living connection between modern and biblical Israel.

Nevertheless, precisely because the issue was so sensitive, had the planners of 1983 been given the opportunity to complete their operational preparations, it is possible that they would have refrained from replacing Israel's currency or would at least have avoided headlining their program as dollarization. The media framing of the plan in this way most probably reflected the malicious intent of whoever was responsible for the leak. At the same time these misfortunes were not unrelated to the inferior power resources and experience of those responsible for the Aridor-Plessner program. In our judgment the premature disclosure of the dollarization plan resulted primarily from the weak cohesion of its planning team-a key collective power resource for ideational entrepreneurs.

We propose a similar interpretation of the unsuccessful framing of the dollarization plan vis-à-vis the professional economics community, that is, in the sphere of coordinative discourse. In this context the dollarization label contributed to perceptions of the plan as professionally superficial by signaling that the planners were unduly focused

\footnotetext{
${ }^{81}$ Cox 2001; Torfing 1999.

${ }^{82}$ Schmidt 2009, 14.

${ }^{83}$ Bruno 1990.
} 
on the tactical challenge of eliminating an inflationary bubble, rather than on the strategic priority of dealing with the fundamental illnesses afflicting the Israeli economy. Although the hyperinflationary crisis spurred experts to float a wide variety of proposals, virtually all academic economists shared the belief that the role of government in the Israeli economy was excessive and harmful. The inclusion of structural reforms and public sector layoffs in the 1985 stabilization program can be interpreted as a framing decision designed to garner legitimacy from economists unconvinced by the plan's unorthodox approach to halting inflation. A similar framing advantage was yielded by supplementing the plan's core component of freezing the exchange rate with orthodox measures of monetary and fiscal restraint. ${ }^{84}$ It is true that the dollarization plan also included proposals to increase monetary and budgetary discipline. But the limited symbolic assets held by the plan's formulators, and their inability to control its framing, made it harder for their voices to be heard by other economic experts.

To the extent that the ideational entrepreneurs behind the stabilization plan benefited from the opportunity to learn from errors committed by their predecessors, this would challenge the independence and therefore the comparability of our two cases. How serious is the fact that dollarization came first, thereby providing an opportunity for social learning to take place? In Hall's words, social learning is "a deliberate attempt to adjust the goals or techniques of policy in response to past experience and new information." ${ }^{85}$ In relation to "past experience," the most important question is whether the earlier plan played an inspirational role in shaping the later one. Participants' accounts suggest that this was not the case. ${ }^{86}$

Concerning "new information," as was noted earlier in the article, while in some respects the economic crisis worsened over the course of the twenty months that elapsed between the two initiatives, examination of key indicators indicates that some became more ominous, others less so, and still others were equally disturbing in both periods. ${ }^{87} \mathrm{In}$

${ }^{84}$ That at least some of these measures were incorporated in the stabilization plan largely out of framing considerations is suggested by the fact that the demand for public sector layoffs was understood from the outset as symbolic (Barkey 1994, 60; Bruno 1985, 214).

${ }^{85}$ Hall 1993, 278.

${ }^{86}$ Nevertheless, because the dollarization plan is universally remembered as an embarrassing failure, economists linked to the stabilization plan who might have been influenced by the previous initiative may be anxious to distance themselves from it.

${ }^{87}$ As discussed in relation to Figure 1, inflation greatly increased for roughly a year after the dollarization plan was revealed, but during the first half of 1985 some improvements were registered in both inflation and the balance of payments. In addition, although the details differ, alarm bells like declining foreign reserves and rising public expenditure deficits were sounded prior to both economic plans. 
any event, there is no evidence that the ideas behind the stabilization plan were inspired by perceptions of either a quantitative or qualitative change in the economic problems that needed to be addressed. Indeed, the two most influential academic economists active in the policy arena offered consistent proposals throughout the hyperinflationary era. Bruno first publicly advocated nominal anchoring several years before the dollarization plan was drawn up, ${ }^{88}$ whereas Berglas continued to question the idea even when helping to finalize the stabilization plan in 1985.

If we broaden our view of social learning to encompass political learning, it is arguable that this did play a role. In all likelihood, members of the stabilization team consciously took steps to avoid making the kind of mistakes that brought about the premature demise of dollarization. For example, only a few weeks after the idea of wholesale adoption of the dollar was abandoned, Bruno circulated a counterproposal that instead of forfeiting Israel's currency would have tied it to the dollar, but under a new name (the sela, or rock). ${ }^{89}$ The intense secrecy under which the stabilization plan was prepared and the selection of team members primarily on the basis of interpersonal trust grounded in previous experience were clearly intended to preempt unplanned or unmanaged disclosure.

At the same time, the contrast between the blunders of the dollarization team and the political skill of the stabilization team should not be exaggerated. The architects of dollarization, Plessner and Aridor, were clearly aware of the importance of marketing their program. This explains why they made efforts to involve economics professors from high-status local universities - but these efforts were unsuccessful, and this in turn made it more difficult to enlist the cooperation of central bank economists. Attempts to obtain endorsements from leading American economists were also unsuccessful, as were the efforts of dollarization planners to maintain secrecy. These failures resulted not only from tactical errors (from which their successors may have learned valuable lessons) but also, more fundamentally, from their lack of power resources that would have rendered their marketing efforts more compelling and effective.

Hence, in our judgment even political learning played a limited role. As we argued earlier in relation to the framing advantage of the stabilization team, whether new policy ideas are perceived as attractive or repellent depends not only on their content but also on who advo-

${ }^{88}$ Bruno 1981.

${ }^{89}$ Bruno 1993, 91. 
cates them and who controls the framing process - their individual and group-level power resources and the conversion of these resources into political capital. As we shall now explain, the political context in which ideas are received also plays a critical role, primarily by conditioning the readiness of decision makers to entertain radical suggestions by ideational entrepreneurs.

\section{Political Contingencies}

Our question is what determines the success of carriers of radical proposals for policy innovation in turning their ideas into policy. As has been pointed out by others, the impact of new ideas depends on the opening (or closing) of a political window of opportunity at a given moment in time. ${ }^{90}$ By describing these as political contingencies, we wish to differentiate them from more stable conditions that facilitate or retard policy innovation. These include both the structure of political institutions and the underlying features of electoral politics like polarization of the party system and voter volatility, all of which remained essentially unchanged in the short period during which the two heterodox economic plans were floated. ${ }^{91}$

Which political contingencies are most important depends on the institutional setting. In the American case, Kingdon identified factors such as a change of administration, an influx of new members of Congress, or a shift in the "national mood" as potentially opening up short-run political opportunities for policy innovation. ${ }^{92}$ In the Israeli context in the period under study, the most important conjunctural factors were the composition of the governing coalition and the scope for harmonious political exchange between the state and corporatist peak associations. ${ }^{93}$

\section{DOLlarization Plan}

Work on the dollarization plan took place during the second term of the Likud government. Since the coalition formed by the Likud rested on a bare majority of members of the legislature (the Knesset), the politi-

${ }^{90}$ See, for example, Hansen and King 2001; Kingdon 1995.

${ }^{91}$ On electoral politics, see Arian 2005.

92 Kingdon 1995.

${ }^{93}$ We therefore reject the claim that the most important political factor explaining the government's adoption of the stabilization program was that "the public believed that the government's economic policies were credible" (Reuveny 1997, 99). Our interpretation is, instead, much closer to that of Grinberg 1991, with the important difference that whereas Grinberg interpreted the political conditions reviewed here as determinants of state autonomy, we are interested in the role they played in conditioning the impact of expert policy advocates. 
cal space for radical policy measures was obviously limited. This helps explain why Prime Minister Yitzhak Shamir so hastily dissociated his government from the dollarization plan after its public disclosure. The next general elections were less than a year away and Shamir had only just taken over the premiership and renegotiated a precarious coalition following the unexpected resignation of his predecessor, Menachem Begin. The government was preoccupied with minimizing the political costs of Israel's continuing occupation of southern Lebanon and with managing damage control following the burst of a stock market bubble, with disastrous consequences for many Israeli families, only a few days before the dollarization plan was reported in the press.

The relationship between the government and the peak labor organization, the Histadrut, was strained in this period, in part because the former was led by the Likud while the latter was a Labor Party bastion. For most of the period following the political upheaval of 1977, when the Likud brought an end to four decades of Labor hegemony, the Histadrut acted as an effective opposition to Likud governments and tried to jeopardize economic policies that were considered harmful, especially if they threatened its institutional interests. The finance ministers of the Likud-led coalitions that ruled Israel between 1977 and 1984 alternated between realpolitik, expressed in relatively harmonious give-and-take with the Histadrut, and strategic attempts to undermine its ability to provide the infrastructure for Labor Party power and to challenge the state's autonomy in economic policy-making. ${ }^{94}$

During Aridor's term as finance minister (January 1981-October 1983), when the dollarization program was under construction, confrontations between the government and the Histadrut peaked. The most prominent struggle concerned the cost-of-living allowance, then the principal mechanism of national-level wage determination in Israel. In what Histadrut leaders interpreted as a bid to undermine their pivotal position in the political economy, Aridor and Plessner proposed the introduction of automatic full indexation and Aridor snubbed Histadrut leaders in favor of attempts at direct negotiations with labor activists. ${ }^{95}$

\section{Stabilization Plan}

Following the 1984 elections neither the Labor Party, which won a narrow victory at the polls, nor the rival Likud Party was able to form

\footnotetext{
${ }^{94}$ Ben-Porath 1983; Grinberg 1991.

${ }^{95}$ Grinberg 1991 and Shalev and Grinberg 1989 provide a comprehensive review and analysis of Histadrut-government relations during the first half of the 1980s. Unless otherwise stated, these are also the sources on which the following section on the stabilization plan relies.
} 
a government. In the end the parties formed a grand coalition in which they rotated the premiership over the next four years. However, this "government of national unity" was not an inevitable outcome of the election results. It also reflected the cooperating parties' will to pursue radical economic reform and to extricate the Israeli army from Lebanon. The grand coalition gave both of them good reason to keep the unity government intact and support its main policy initiatives. Its first major achievement was to withdraw the Israel Defense Forces from most of Lebanon.

Although the Israeli withdrawal could be seen as having opened up the political space needed for tackling the economic crisis-arguably, the opposite of the role played by the Lebanon war at the time dollarization was unveiled-we interpret both the geopolitical and the economic initiatives taken by the new bipartisan government as deriving from the same political complementarities. Just as shared responsibility minimized the elements of contentiousness and blame that had previously rendered withdrawal so intractable, it also eased the obstacles to adopting stringent remedies for the economic crisis. Labor needed the Likud in order to gain popular legitimacy and counter opposition from the right, while its presence in the government vastly increased the chances of Histadrut cooperation.

When the stabilization plan was brought before the government, most Likud ministers voted against it in protest against the planned budget cuts. However this opposition was essentially pro forma, and majority support for the plan was almost a foregone conclusion. For instance, although Ariel Sharon, the minister of industry and commerce, voted against the program in the cabinet, he cooperated fully with its implementation. ${ }^{96}$ Sharon's cooperation was crucial, as his ministry was responsible for planning and administering the price freeze that was an integral part of the plan.

The Histadrut reacted to the stabilization plan with angry rhetoric and even launched a one-day general strike, but this too was primarily a token response. In order to increase the chances of Histadrut cooperation, the stabilization plan had been put on hold until after Histadrut elections, when the Labor Party candidate for the position of secretary-general was safely in office. Nonetheless, the Histadrut's readiness to go along with the program was far from guaranteed since it included measures that undermined its trade union interests-namely, wage control by means of government decrees and the dismissal of ten

\footnotetext{
${ }^{96}$ Sharon-INT 2007.
} 
thousand public sector employees. Informal negotiations between the Labor Party and Histadrut leaders ${ }^{97}$ yielded a compromise that included reductions in targets for real wage erosion and public sector layoffs. The government also retracted its intention of implementing wage cuts by administrative fiat rather than through collective bargaining. In the background were informal understandings between Histadrut and Labor Party leaders that the latter would use their position in the government to increase state subsidies to the labor organization's business enterprises and health care system - the pillars of its economic and organizational power-which were in dire financial straits.

Clearly, political conditions for the adoption of radically innovative economic policies were far more propitious in the run-up to the stabilization plan than they had been two years earlier. The favorable conjuncture in the corporatist political arena seems to have played a particularly important role in giving decision makers the confidence to proceed in 1985. Still, the premature unveiling of the dollarization plan and its hasty burial make it difficult to be certain whether fears of Histadrut resistance would ultimately have caused top politicians and bureaucrats to refrain from approving the plan. In contrast, it is easy to see the difference that parliamentary politics made to the fate of the two proposals. After two humiliating electoral defeats, the Labor Party seized on the opportunity to undermine the narrow Likud coalition formed in October 1983 by publicly discrediting dollarization. Following the plan's surprise revelation, Labor leader Shimon Peres declared that " $[t]$ he country has never been in the hands of such an incompetent group with such dangerous ideas." ${ }^{98}$ Dollarization was presented as an absurd proposal sired by irresponsible politicians and their advisers-a theme that the Labor Party (and most economists) had been loudly articulating ever since Aridor's allegedly populist economic policies helped return the Likud to power in 1981. In line with our earlier argument, such sweeping delegitimation would have been less credible in relation to the stabilization plan, given the stature of the experts responsible for it. But it is also clear that the change in circumstances after the 1984 elections would have granted any credible economic plan a significant degree of immunity from opposition motivated by competition between Labor and Likud. Neither party would have had an incentive to discredit either the plan or its authors.

\footnotetext{
${ }^{97}$ The head of the Manufacturers' Association, who was close to the Labor Party, was also involved in these negotiations (Bruno 1993, 99; Gavish-INT 1988; Neubach-INT 2007).

98 "Israel: Unhatched Egg." 1983. Time Magazine. October 24, at http://www.time.com/time/ magazine/article/0,9171,926277,00.html. Accessed October 20, 2009.
} 
Under the circumstances, it might be tempting to suggest that political contingencies overdetermined the failure of dollarization and the success of stabilization. To address this issue properly requires posing a counterfactual: would the advocates of dollarization have succeeded in winning its acceptance had their plan been proposed under the political circumstances prevailing when the stabilization plan was endorsed? We think not. The inferior academic and political capital of the promoters of dollarization would have limited their ability to compete with alternative policy proposals, even under political conditions (like those prevailing in June 1985) that silenced partisan opponents and neutralized the most important economic veto player. Correspondingly, the absence of a favorable window of political opportunity, as was the case in October 1983, makes it very difficult for expert advocates to win approval for radical policy innovation. Success may not be impossible for a team that is richly endowed with politically relevant resources and experience. However, since our natural experiment lacks a configuration in which powerful advocates coincided with inopportune political circumstances, we cannot offer any empirically based assessment of this possibility.

In evaluating the role of political contingencies, it is critical to bear in mind that the primary question animating our analysis is not when governments may be ready to embrace radical policy proposals but which proposals - if any-they are likely to endorse. As Campbell has pointed out, ${ }^{99}$ it is often the case that "the process of institutional change involves several entrepreneurs jockeying for position and competing to win the favor of ... decision makers." This is the most important reason that favorable political contingences play only a secondary role in our analysis. Ideational entrepreneurs never operate in a sterile environment. In our own case study unfortunate framing decisions, weak coordination, lack of social and political capital, and other shortages of power resources had the effect of increasing the vulnerability of the dollarization team to both internal dissension and external competition with the advocates of alternative policy proposals. By contrast, the stabilization team was able to use its advantageous individual and collective power resources to present itself as the most authoritative available body of experts, to prevent competitors from challenging its superior standing, and to avoid blunders that would have undermined the political feasibility of its proposals. By enhancing the government's readiness to consider far-reaching policy shifts, a conjuncture that sup-

\footnotetext{
${ }^{99}$ Campbell 2004, 179.
} 
plied a sturdy coalition and had the effect of subduing potential opponents made it easier for the voices of powerful ideational entrepreneurs to be heard. In this spirit, political contingencies should be seen, at most, as a necessary but insufficient condition for the adoption of a program of radical reform.

\section{Conclusions}

Our paired comparison between a successful and a failed attempt to gain acceptance of very similar economic reforms supports the view that new ideas have an impact only if their carriers hold and strategically exploit sufficient power resources and if the political circumstances under which these agents operate furnish a viable window of opportunity. Needless to say, this hardly constitutes-nor is it intended to - an exhaustive compendium of the causes of major institutional changes in economic policy or any other area of state activity. It is precisely the virtue of our case study that it offers an unusual opportunity to set aside the usual suspects and zoom in on neglected but potentially critical explanatory forces. Schmidt has felicitously synthesized many of the relevant variables in her suggestion that "[d]iscourse is not just ideas or 'text' (what is said) but also context (where, when, how, and why it was said). The term refers not only to structure (what is said, or where and how) but also to agency (who said what to whom)."100 On the one hand, our comparison has revealed considerable similarity in what was said (the content of the two programs), when it was said (an economic crisis pregnant with uncertainty), and where (essentially the same institutional and political-economic context). On the other hand, we have pointed to significant differences with regard to who the idea carriers were (and consequently their differential power resources), how they operated (their functioning as groups), and when (the specific political circumstances they faced). We acknowledge, of course, that no naturally occurring comparison can furnish a research design that controls for everything. We concede that since the dollarization plan preceded the stabilization plan, the first might have "contaminated" the second. Our argument on this point is that disadvantages like the inferior framing of the first plan in comparison with the second were more a reflection of the power resources of its advocates than of the opportunity of the latecomers to learn valuable political lessons from their predecessors.

${ }^{100}$ Schmidt 2008, 305, emphases added. 
With the exception of the important programmatic statement by Campbell cited in our introductory remarks,${ }^{101}$ the literature on discursive institutionalism has so far paid very little attention to the power of ideational entrepreneurs or to the windows of opportunity opened or closed by the political conjunctures in which they operate. The major concerns have been identifying the conditions under which ideational influence is most likely to occur, categorizing different kinds of ideas and ideational influence, and weighing the explanatory role of ideas in generating institutional change-either compared with or combined with the influence of other factors. When addressing the question of why some ideas are more influential than others, analysts have focused mainly on innate qualities of the ideas concerned-their simplicity, coherence, relevance, or conformity with actors' existing perceptions and with past institutional legacies. ${ }^{102}$ Acknowledging the importance of the factors privileged by our account does not erode the explanatory power of ideas. Instead, it highlights previously neglected sources of the persuasiveness of their advocates. In particular, recognizing the power of idea carriers does not mean reducing ideational influence to the result of power relations. But persuasion is a political process, and politics cannot be conducted without power.

Part of this article's contribution to understanding the politics of persuasion has been to break down key elements of the power resources of expert idea carriers into distinct conceptual categories that have definable empirical referents. In this context we have found that Bourdieu's approach provides a valuable way of disaggregating power resources into different types and understanding the relationships between them. In turn, the advocacy coalition and policy transfer frameworks offer concepts with clear empirical referents for identifying group-level power resources. Given the existence of rich and far-flung literatures on both power and ideas, future research on the power of idea carriers may also benefit from venturing into unfamiliar territory.

Finally, the research design utilized in this project offers a broader methodological lesson. The desire to explain institutional change should not direct our attention exclusively to cases in which ideational entrepreneurs succeed in bringing about changes. As demonstrated in this article and by a limited number of earlier studies based on a similar design, ${ }^{103}$ comparisons of successful and failed initiatives offer persua-

\footnotetext{
${ }^{101}$ Campbell 2004.

${ }^{102}$ See, for example, Blyth 2007; Campbell 1998; Hall 1989.

${ }^{103}$ See, for example, Dimitrakopoulos 2005; Hansen and King 2001; Schmidt 2009.
} 
sive lessons regarding the conditions for radical innovation in public policy, including the state's management of the economy.

\section{APPENDIX \\ INTERVIEWS}

Unless otherwise stated, interviews were conducted by Ronen Mandelkern. The affiliations of interviewees refer to the period under study, 1983-85.

Aridor, Yoram. 2007. Minister of Finance (until October 1983). Interviewed on November 21.

Ben Basat, Avraham. 2007. Bank of Israel, Deputy Head of Research Department. Interviewed on November 15.

Berglas, Eitan. 1988. Department of Economics, Tel Aviv University. Interviewed by Lev Grinberg, Michael Shalev, and Yuval Yonay on July 13.

Bruno, Michael. 1988. Department of Economics, Hebrew University of Jerusalem. Interviewed by Lev Grinberg and Michael Shalev on October 25.

Fogel, Aharon. 2007. Ministry of Finance, Head of Budgets Division (since January 1984). Interviewed on November 22.

Frenkel, Mordechai. 2007. Bank of Israel, Head of Research Department. Interviewed on November 12.

Gavish, Yeshayahu (Shaike). 1988. Managing Director of Koor Industries. Interviewed by Lev Grinberg, Michael Shalev, and Yuval Yonay on July 6.

Gross, Nachum. 2006. Department of Economics, Hebrew University of Jerusalem. Interviewed on October 25.

Liviatan, Nissim. 2007. Department of Economics, Hebrew University of Jerusalem; Bank of Israel, Consultant to the Research Department. Interviewed on June 11.

Mandelbaum, Moshe. 1988 and 2007. Bank of Israel, Governor. Interviewed by Lev Grinberg, Michael Shalev, and Yuval Yonay on July 22, 1988, and by Ronen Mandelkern on December 21, 2007.

Meridor, Liora. 2007. Bank of Israel, Senior Researcher at the Research Department. Interviewed on December 11.

Neubach, Amnon. 2007. Economic Adviser to the Prime Minister (since September 1984). Interviewed on December 12.

Plessner, Yakir. 2007 and 2008. Adviser to the Minister of Finance (until late 1983); Bank of Israel, Deputy Governor; Department of 
Agricultural Economics, Hebrew University of Jerusalem. Interviewed on August 8, 2007; additional e-mail correspondence, March 9, 2008.

Rubin, Amos. 1988 and 2007. Bank of Israel, Senior Researcher. Interviewed by Michael Shalev and Yuval Yonay on July 21, 1988, and by Ronen Mandelkern on July 30, 2007.

Sadan, Ezra. 2007. Ministry of Finance, Director-General (until late 1983); Department of Agricultural Economics, Hebrew University of Jerusalem. Interviewed on November 18.

Sharon, Emmanuel. 2007. Ministry of Finance, Director-General (from September 1984). Interviewed on November 11.

\section{REFERENCES}

Al Ha'Mishmar. 1983. "Why Dollarization: Economic Policy Alternatives" (in Hebrew). November 1.

Arian, Alan. 2005. Politics in Israel: The Second Republic. Washington, D.C.: CQ Press.

Barber, William J. 1989. "The Spread of Economic Ideas between Academia and Government: A Two-Way Street.” In D. C. Colander and A. W. Coats, eds., The Spread of Economic Ideas. Cambridge: Cambridge University Press.

Barkey, Henri. 1994. "When Politics Matter: Economic Stabilization in Argentina and Israel." Studies in Comparative International Development (SCID) 29, no. 4: 41-67.

Ben-Porath, Yoram. 1983. "The Conservative Turnabout That Never Was.” Jerusalem Quarterly, no. 29 (Fall): 3-10.

Harvard University Press.

Berman, Sheri. 2001. "Ideas, Norms, and Culture in Political Analysis." Comparative Politics 33, no. 2 (January): 231-50.

Blaug, Mark, and R. P. Sturges. 1983. Who's Who in Economics: A Biographical Dictionary of Major Economists, 1700-1981. Cambridge: MIT Press.

Blyth, Mark. 2001. "The Transformation of the Swedish Model: Economic Ideas, Distributional Conflict, and Institutional Change." World Politics 54, no. 1(October): 1-26.

- 2002. Great Transformations: Economic Ideas and Institutional Change in the Twentieth Century. New York: Cambridge University Press.

_ 2003. "Structures Do Not Come with an Instruction Sheet: Interests, Ideas, and Progress in Political Science." Perspectives on Politics 1, no. 4: 695706.

- 2007. "Powering, Puzzling, or Persuading? The Mechanisms of Building Institutional Orders." International Studies Quarterly 51, no. 4: 761-77.

Bourdieu, Pierre. 1986. "The Forms of Capital.” In J. G. Richardson, ed., Handbook of Theory and Research for the Sociology of Education. New York: Greenwood Press. 
1988. Homo Academicus. Stanford, Calif.: Stanford University Press.

Bourdieu, Pierre, and Loïc Wacquant. 1999. "On the Cunning of Imperialist Reason." Theory Culture and Society 16, no. 1: 41-58.

Brodet, David. 2005. “The Government's Self-Confidence Was Generated by the Stabilization Program” (in Hebrew). The Marker. July 1: 16-17.

Bronfeld, Shaul. 1975. "Post-1973 Monetary Trends" (in Hebrew). Riv'on Le'Kalkala 22, no. 87: 277-88.

Bruno, Michael. 1981. "A Decisive Blow" (in Hebrew). Migran, no. 56, 33-38.

. 1985. "Economic Stabilization: The Emergency Plan in Its Early Phase" (in Hebrew). Riv'on Le'Kalkala 32, no. 126: 207-23.

-1986. "External Shocks and Domestic Response: Israel's Macroeconomic Performance, 1965-1982.” In Y. Ben-Porath, ed., The Economy of Israel: Maturing through Crisis. Cambridge: Harvard University Press.

-1990. "Economic Analysis and the Political Economy of Policy Formation.” European Economic Review 34, no. 2-3: 273-301.

-1993. Crisis, Stabilization, and Economic Reform: Therapy by Consensus. Oxford: Clarendon Press.

Bruno, Michael, Guido Di Tella, Rudiger Dornbusch, and Stanley Fischer. 1988. Inflation Stabilization: The Experience of Israel, Argentina, Brazil, Bolivia, and Mexico. Cambridge: MIT Press.

Bruno, Michael, and Stanley Fischer. 1986. "The Inflationary Process in Israel: Shocks and Accommodation." In Y. Ben-Porath, ed., The Economy of Israel: Maturing through Crisis. Cambridge: Harvard University Press.

Campbell, John L. 1998. "Institutional Analysis and the Role of Ideas in Political Economy." Theory and Society 27, no. 3 (June): 377-409.

- 2004. Institutional Change and Globalization. Princeton: Princeton University Press.

Campbell, John L., and Ove Kaj Pedersen, eds. 2001. The Rise of Neoliberalism and Institutional Analysis. Princeton: Princeton University Press.

Cox, Robert H. 2001. "The Social Construction of an Imperative: Why Welfare Reform Happened in Denmark and the Netherlands but Not in Germany." World Politics 53, no. 3 (April): 463-98.

Dimitrakopoulos, Dionyssis G. .2005. "Norms, Interests and Institutional Change." Political Studies 53, no. 4: 676-93.

Dollarization Colloquim. 1984. "Dollarization - the Arguments for and againsta Colloquium” (in Hebrew). Riv'on Le'Kalkala 31, no. 121: 124-42.

Evans, Mark, and Jonathan Davies. 1999. "Understanding Policy Transfer: A Multi-Level, Multi-Disciplinary Perspective." Public Administration 77, no. 2: 361-85.

Fischer, Stanley. 2001. Remembering Herb Stein-His Contributions as an Economist: Address by Stanley Fischer, at http://www.imf.org/external/np/speeches/ 2001/010601.htm. Accessed July 23, 2007.

Fischer, Stanley, and Jacob A. Frenkel. 1982. "A Stabilization Program for Israel” (in Hebrew). Riv'on Le'Kalkala 29, no. 114: 246-55.

Fourcade, Marion. 2009. Economists and Societies: Discipline and Profession in the United States, Britain, and France, 1890s to 1990s. Princeton: Princeton University Press.

Gafni, Arnon. 1977. "Economic Growth While Reducing Dependence" (in Hebrew). Riv'on Le'Kalkala 24, no. 94: 175-85. 
Goldstein, Judith. 1993. Ideas, Interests, and American Trade Policy. Ithaca, N.Y.: Cornell University Press.

Goldstein, Judith, and Robert O. Keohane. 1993. Ideas and Foreign Policy: Beliefs, Institutions, and Political Change. Ithaca, N.Y.: Cornell University Press.

Grinberg, Lev Luis. 1991. Split Corporatism in Israel. Albany: State University of New York Press.

Gronau, Reuven, David Levhari, Micha Michaeli, and Michael Bruno. 1984. "Economic Policy in the Wake of the Crisis-A Symposium" (in Hebrew). Riv'on Le'Kalkala 30, no. 119: 838-47.

Gross, Nachum. 2004. "Economic Policy in Israel in the Eyes of Senior Economists in the Bank of Israel" (in Hebrew). In N. Liviatan and H. Barkai, eds., Bank of Israel: Fifty Years of Striving for Monetary Control. Jerusalem: Bank of Israel.

Haas, Peter M. 1992. "Epistemic Communities and International Policy Coordination.” International Organization 46, no. 1: 1-35.

Hall, Peter A. 1989. "Conclusion: The Politics of Keynesian Ideas." In P. A. Hall, ed., The Political Power of Economic Ideas: Keynesianism across Nations. Princeton: Princeton University Press.

- 1993. "Policy Paradigms, Social-Learning, and the State: The Case of Economic Policy-Making in Britain." Comparative Politics 25, no. 3: 275-96.

Hansen, Randall, and Desmond King. 2001. "Eugenic Ideas, Political Interests, and Policy Variance: Immigration and Sterilization Policy in Britain and the U.S." World Politics 53, no. 2 (January): 237-63.

Hay, Colin. 2001. "The 'Crisis' of Keynesianism and the Rise of Neoliberalism in Britain: An Ideational Institutional Approach.” In J. L. Campbell and O. K. Pedersen, eds., The Rise of Neoliberalism and Institutional Analysis. Princeton: Princeton University Press.

Keren, Michael. 1995. Professionals against Populism: The Peres Government and Democracy. Albany: State University of New York Press.

King, Desmond S. 1999. In the Name of Liberalism: Illiberal Social Policy in the USA and Britain. Oxford: Oxford University Press.

Kingdon, John W. 1995. Agendas, Alternatives, and Public Policies. New York: HarperCollins College Publishers.

Kleiman, Ephraim. 1984. "Costs of Inflation” (in Hebrew). Riv'on Le'Kalkala 30, no. 119: 859-64.

- 1997. “The Waning of Israeli Etatisme.” Israel Studies 2, no. 2: 146-71.

Leiderman, Leonardo, Haim Ben-Shahar, Abraham Shavit, Michael Bruno, and Eitan Berglas. 1979. "Balance of Payments, Foreign Debt and the Economic Policy: A Symposium” (in Hebrew). Riv'on Le'Kalkala 26, no. 103: 368-86.

Levi-Faur, David. 1999. "Warfare, Polity-Formation and the Israeli National Policy Patterns.” Israel Affairs 5, no. 2-3: 156-68.

Lindvall, Johannes. 2009. "The Real but Limited Influence of Expert Ideas." World Politics 61, no. 4 (October): 703-30.

Liviatan, Nissan, and Haim Barkai. 2004. Bank of Israel: Fifty Years of Striving for Monetary Control (in Hebrew). Jerusalem: Bank of Israel.

Liviatan, Nissan, and Sylvia Piterman. 1984. Accelerating Inflation and Balance of Payments Crises: Israel 1973-1984 (in Hebrew). Jerusalem: Bank of Israel Research Department.

Maman, D., and Z. Rosenhek. 2007. "The Politics of Institutional Reform: The 
'Declaration of Independence' of the Israeli Central Bank." Review of International Political Economy 14, no. 2 (May): 251-75.

Mandelkern, Ronen. 2006. "Ideational Semiperiphery: Israeli Economics as a Case Study." Paper presented at the Workshop on Policy Ideas, Discourses and Debates in the Globalisation Process: Have Developing Countries a Chance to Compete? Nicosia, April 26-29.

Mundlak, Guy. 2007. Fading Corporatism: Israel's Labor Law and Industrial Relations in Transition. Ithaca, N.Y.: ILR Press/Cornell University Press.

Nitzan, Jonathan, and Shimshon Bichler. 2002. The Global Political Economy of Israel. London: Pluto Press.

Payne, Rodger A. 2001. "Persuasion, Frames and Norm Construction." European Journal of International Relations 7, no. 1: 37-62.

Pines, David, and Assaf Razin. 1985. "The Plessner Program: Bubbles Floating in the Air." In A. Razin, ed., Economists on Economy: Views from Tel Aviv University (in Hebrew). Tel Aviv: Ramot Publishing-Tel Aviv University.

Plessner, Yakir. 1983. "The Theoretical and Empirical Foundation of Recent Israeli Economic Policy and Its Objectives" (in Hebrew). Riv'on Le'Kalkala 30, no. 118: 741-57.

- 1984a. "Dollarization: Monetary Stabilization Theory and Application" (in Hebrew). Riv'on Le'Kalkala 31, no. 120: 22-32.

- 1984b. "A Further Note on Dollarization, Wages, Devaluations and Inflation” (in Hebrew). Riv'on Le'Kalkala 31, no. 122: 292-98.

- 1994. The Political Economy of Israel: From Ideology to Stagnation. Albany: State University of New York Press.

Plessner, Yakir, and Warren Young. 2005. "Economists, Government, and Economic Policymaking in Israel: From 'Crawling Peg' To 'Cold Turkey.” History of Political Economy 37, Supplement 1: 292-313.

Radaelli, Claudio M., and Vivien A. Schmidt. 2004. "Special Issue on Policy Change and Discourse in Europe: Conclusions." West European Politics 27, no. 2 (March): 364-79.

Razin, Assaf. 1984a. "The Economy and Alternative Plans" (in Hebrew). Riv'on Le'Kalkala 31, no. 123: 329-33.

- 1984b. "The Israeli Economy: 1983" (in Hebrew). Riv'on Le'Kalkala 31, no. 119: 834-37.

Razin, Assaf, Gad Yaacobi, Elchanan Helpman, and Eli Hurvitz. 1985. "Current Economic Policy: A Symposium” (in Hebrew). Riv'on Le'Kalkala 32, no. 124: 3-11.

Reuveny, Rafael. 1997. "Democracy, Credibility, and Sound Economics: The Israeli Hyperinflation.” Policy Sciences 30, no. 2: 91-111.

Risse-Kappen, Thomas. 1994. "Ideas Do Not Float Freely: Transnational Coalitions, Domestic Structures, and the End of the Cold War." International Organization 48, no. 2: 185-214.

Risse, Thomas. 2000. “Let's Argue!': Communicative Action in World Politics.” International Organization 54, no. 1: 1-39.

Rubin, Amos. 1984. "It Is Possible and Preferable to Immediately Stop Spiraling Inflation" (in Hebrew). Jerusalem, unpublished report.

Sabatier, Paul A. 1998. "The Advocacy Coalition Framework: Revision and Relevance for Europe." Journal of European Public Policy 5, no. 1: 98-130. 
Sabatier, Paul A., and Hank C. Jenkins-Smith. 1993. Policy Change and Learning: An Advocacy Coalition Approach. Boulder, Colo.: Westview Press.

Schmidt, Vivien A. 2008. "Discursive Institutionalism: The Explanatory Power of Ideas and Discourse." Annual Review of Political Science 11: 303-26.

- 2009. "Putting the Political Back into Political Economy by Bringing the State Back in Yet Again.” World Politics 61, no. 3 (July): 516-46.

Shalev, Michael. 1992. Labour and the Political Economy in Israel. Oxford: Oxford University Press.

Shalev, Michael, and Lev Grinberg. 1989. "Histadrut-Government Relations and the Transition from a Likud to a National Unity Government: Continuity and Change in Israel's Economic Crisis.” Discussion Paper 19-89, Pinhas Sapir Center for Development, Tel Aviv University, October.

State of Israel. 1985. "Emergency Economic Stabilization Plan. Government Decision No. 707 2/7/1985" (in Hebrew). Jerusalem.

Steinmo, Sven. 2008. "Historical Institutionalism." In D. Della Porta and M. Keating, eds., Approaches and Methodologies in the Social Sciences: A Pluralist Perspective. New York: Cambridge University Press.

Stone, Diane. 2002. "Introduction: Global Knowledge and Advocacy Networks." Global Networks: A Journal of Transnational Affairs 2, no. 1: 1-12.

Swartz, David. 1997. Culture and Power: The Sociology of Pierre Bourdieu. Chicago: University of Chicago Press.

Torfing, Jacob. 1999. “Towards a Schumpeterian Workfare Postnational Regime: Path-Shaping and Path-Dependency in Danish Welfare State Reform." Economy and Society 28, no. 3: 369-402.

Weir, Margaret. 1989. "Ideas and Politics: The Acceptance of Keynesianism in Britain and the United States." In P. A. Hall, ed., The Political Power of Economic Ideas: Keynesianism across Nations. Princeton: Princeton University Press.

Widmaier, Wesley W., Mark Blyth, and Leonard Seabrooke. 2007. "Exogenous Shocks or Endogenous Constructions? The Meanings of Wars and Crises.” International Studies Quarterly 51, no. 4: 747-59.

Yoran, Yosef. 1978. "Economic Policy and Reality” (in Hebrew). Riv'on Le'Kalkala 25, no. 96-97: 17-36. 